\title{
Investigation of Tax Assessment Challenges of Category "C" Business Income Tax Payers in Debre Markos Town
}

\author{
Adane Wudu Abebaw \\ Lecturer, College of Business and Economics, Department of Accounting and finance, \\ Debre Markos University, Ethiopia
}

\begin{abstract}
This study Investigates Tax Assessment Challenges of Category "C" Business Income Tax Payers In Debre Markos Town. The study adopts a mixed methods research approach by combining data gathering instruments of research questions, in-depth interviews and document analysis. The questionnaire data were analyzed using descriptive statistics, correlations, and logistic regression analysis and data from interview and document reviews were interpreted qualitatively. The findings of the study show that, the five variables which are Tax law enforcement, Taxpayers attitude, Educational level of taxpayers, Level of taxpayers actual income, and Tax system fairness significantly influence the tax collection performance of Debre Markos town tax Authority. The study suggests that the tax authority should create awareness towards the taxpayers why tax are levied from them and change the negative attitude of taxpayers towards tax. The tax authority should be clear of the way of tax estimation, what and how presumptive taxation applicable to tax payers through discussion agendas with taxpayers.
\end{abstract}

Keywords: Tax assessment, business income tax payers, category ' $\mathrm{C}$ ' taxpayers, presumptive taxation

DOI: $10.7176 /$ RJFA/11-7-02

Publication date: April $30^{\text {th }} 2020$

\section{Introduction}

\subsection{Background of the study}

A tax is a compulsory payment or contribution by the people to the government for which there is no direct return to the tax payers. Tax imposes a personal obligation on the people to pay if they are liable to pay it. The general public should be taxed according to their ability to pay i.e. the people in the same financial position should be taxed in the same way (Prichard 2010).

Business income taxes are important source of revenue to government in both developing and developed countries. However, the amount revenue to be generated by government from such tax for its expenditure program depends among other things, on the willingness of taxpayers to comply with tax laws of a country (Eshag 1983).

Business income tax called profit tax or schedule "C: tax is an income tax" imposed by the government on taxable business income profit of a business realized from entrepreneurial activities' arising each tax years (Misrak Tasfay 2008). According to current Ethiopia federal income tax proclamation No 979/2016 tax payers are categorized in to three namely "A", "B" "C" of business income tax payers. All tax payers which annual turnover income is less than 500,000 in Ethiopia birr grouped as category "C" taxpayers. This category of tax payers are not required to keep books or prepared financial statements. Their income tax liability is determined through a special procedure known as presumptive taxation. The principle of presumptive taxation is imposed on those whose income is lower who are not covered under usual tax coverage and at the same time have taxable capacity. It has also certain advantages; one is simplification, particularly in the case of taxpayers with low turnover. Second, presumptive taxes are effective in reducing tax avoidance. However, tax assessment and collection form category "C" has many challenges, as they are not required to have book of records. This study therefore aimed to investigate Tax Assessment Challenges of Category "C" Business Income Tax Payers in Debre Markos Town.

\subsection{Statement of the problem}

Business income taxes are important source of revenue to government in both developing and developed countries. As in all other countries one of the purpose of taxation in Ethiopia is the raising of as much revenue as possible to meet the ever- expanding public expenditure for the supply of public goods and services which otherwise would not be available to the public by the market (Sisay 2009). However, Ethiopia faces lower tax collection in comparison to a target amount. For instance a report by the tax authority in Ethiopian revealed that tax revenue to Gross Domestic Product (GDP) ratio is $13.7 \%$ which is very low when it is compared with the ratio of the subSaharan countries.

The capacity of revenue expenditure coverage of Amhara National Regional State (ANRS) as indicated by the report of Amhara Revenue Authority (2017/18) was also low. For instance, in 2018, the revenue was 4.3 billion birr and the government expenditure was 32.8 billion birr in the same fiscal year. This shows the expenditure coverage ability with the tax revenue accounts only $13.12 \%$. This low revenue yield of taxation can be attributed to the fact that tax provisions are not properly enforced either on account of the inability of administration to cope 
with them or on account of straight forward collusion between the tax administration and taxpayers.(Abate 2019). Annual report of Debre Markos town administration revenues authority 2019, show that from the category "C" taxpayers total plan level of revenue only about $71 \%$ was collected which shows a tax administration problem results from either from the authority or taxpayers.

For efficient administration of taxes, clarity of rights and obligations to taxpayers, assessors and collectors should be considered it is worth to understand to increase ability to collect more revenues, with greater efficiency and less public resistance with more public service delivery. In addition to this, tax assessment might ascertain the taxable incomes, possible returns, allowable deductions and others chores of income tax during income tax enforcement. (Abebaw 2019)

In Ethiopia, tax assessment and collection for category "C" taxpayers made by using presumptive taxation (assessment by estimation) by the tax officers. According to Ethiopia federal income tax proclamation No 979 /2016, category "C" taxpayers are not required to have book of records because of high cost of producing financial reports hence tax is collected through estimation. However, presumptive taxation and collection from category " $\mathrm{C}$ " has many challenges, there is a great conflict between taxpayers and income estimation conducted by tax authority; which shows many tax payers found themselves rejecting the daily income estimation and the associate tax levy. The income estimation by the tax authority does not consider the taxpayers actual income, and daily turnover, the taxpayers will not get appropriate answer from tax authority for re- estimation, unskilled and inefficient estimators. On the side of taxpayers, taxpayers are not even willing to pay tax, they lack awareness on why they pay tax, and they have a question on the fairness of tax system and tax administration. Thus, by taking above factors in to account this study therefore aimed to investigate Tax Assessment Challenges of Category "C" Business Income Tax Payers in Debre Markos Town.

\subsection{Objectives of the Study}

The main objective of this study is investigate Tax Assessment Challenges of Category "C" Business Income Tax Payers in Debre Markos Town.

The specific of the study are:

* To assess the factors that affect Debre Markos town tax authority tax collection performance.

\subsection{Hypothesis of the study}

To achieve the objective of this study, the following hypotheses concerning tax collection performance would be tested.

H1: The law enforcement of the authority negatively affects tax collection performance.

H2: tax collection performance positively affected by fair tax system.

H3: positive taxpayers' attitude towards tax affects tax collection performance positively.

H4: Educational level of taxpayers affects tax collection performance positively.

H5: High income of taxpayers affects tax collection performance positively.

\subsection{Significance of the Study}

The findings of the study help taxpayers to improve their attitude towards tax to pay tax at the required time and amount. The study also is considered as fundamental for Ethiopian revenue and customer authority being effective and efficient to provide relevant information knowledge that help tax administrators, policy makers and collector to identify factors that may affect tax collection performance. In addition, the study might help Ethiopian revenue and custom authority to know the problems that need attention to provide solutions and better meet the needs of taxpayers. Finally, the study would help to improve the economy by providing sufficient amount of revenue through tax.

\subsection{Scope of the Study}

This study conducted considering only the business income tax payers of category "C" in Debre Markos town.

\section{Literature review}

\subsection{Tax Assessment}

It is the process of determining the amount of tax revenue to be collected from a taxpayer. A tax assessor is responsible for preparing and maintaining the assessment roll, the tax roll and collecting the tax levies in accordance with the quality standards set. (Abate 2019).

\subsection{Factors determining Tax collection performance}

\subsubsection{Tax law enforcement}

There are two types of methods: the carrot and stick method to enforce the tax low. According to the deterrence view, people carefully assess opportunities and risks, and disobey the law when the anticipated fine and probability 
of being caught are small in relation to the profits to be made through non-compliance. Taxpayers understand a cost benefit analysis and will comply if the benefit exceeds the cost of compliance. Thus, the taxpayer is a utility maximizer. Additionally, taxpayers' behavior of non-compliance depends on their belief of the probability of being detected through an audit and the severity of legal penalties imposed (Allingham and Sandmo, 1972).

The tax law is enforced by systems of fines and penalties in order to promote tax compliance. Taxpayers need to face certain threads of punishment if they do not truthfully declare all their income.

2.2.2 Taxpayers attitude

Attitudes represent the positive and negative evaluations that an individual holds of objects. It is assumed that attitudes encourage individuals to act according to them. Thus, a taxpayer with positive attitudes toward tax evasion is expected to be less compliant than a taxpayer with negative attitudes. Attitudes towards tax evasion are often found to be quite positive (Kirchler et al., 2008)

The attitudes are important for both the power and the trust dimension. On the one hand, favorable attitudes will contribute to trust in authorities and consequently will enhance voluntary tax compliance. On the other hand, attitudes towards the authorities will be relevant for the interpretation of the use of power as benevolent or malicious. Tax attitudes in general also depend on the perceived use of the money collected and therefore are connected to knowledge (Kirchler et al., 2008)

2.2.3 Educational level of taxpayers

Tax knowledge is an essential element in a voluntary compliance tax system (Kasippilai, 2000), Tax Knowledge Self-assessment system can work well if the people have appropriate knowledge of tax regulations. The taxpayer's knowledge shows the understanding of the taxpayer in applying the tax rules particularly on business profit tax.

2.2.4 Level of taxpayers' actual income

It is one the economic factor that influences rental taxpayers' compliance with the tax system. Spicer and Lundstedt (1976) point out that self-employed have more possibilities to avoid taxes than employed taxpayers do. However, self-employed taxpayers have more opportunities for tax evasion and these opportunities might further increase with the number of different income source. Hence, in tax compliance decisions the level of income might interact with its source.

2.2.5 Tax system fairness

Fairness of the income tax and ability to pay is the other key factors which play their own roles on tax collection performance (WBG, 2007). For instance if there is no administrative consistency in respect of the provisions of business profit tax system, there will be contradicts with the principles of fairness across business profit taxpayers. Moreover, the assessments of the income of the tax payers need to be fair and conducted independently and objectively. Thus, the effect of the fairness of tax assessment on tax collection efficiency will be tested.

\section{Research Methodology}

3.1 Research Design

In order to achieve the objectives of this study, the researcher used mixed (both qualitative and quantitative) research approach. Mixed method approach focuses on collecting, analyzing and mixing both quantitative and qualitative data in a single study or series of studies. (John W. Creswell 2013).

\subsection{Target group and sampling technique and sample size}

The target population for this study is personal business income taxpayers who are subject for business profit tax of category " $\mathrm{C}$ " taxpayers. Therefore, the target for the sample included population consists of all business income tax payers in Debre Markos town. There are 3860 category "C" business profit tax payers in Debre markos town, as the information obtained from Ethiopian revenue and custom authority of Debre markos district as the date on 2019.

In the study, the researcher were used judgmental sampling techniques for gathering primary source of data. The reason why the researchers use judgmental sampling techniques is that it is convenient to use effectively and select target respondents that provide relevant information (Wilson M 2008).

In deciding the desired sample size, it is customary to consider the availability of time, resources and the aim of the study. In this regard, by taking this in to account a sample size of 96 if found feasible from 3860 category "C" business income tax payers found in Debre Markos town. In order to determine the sample size Yamane's (1967) sampling size determination formula is used at $90 \%$ confidence level and 0.1 level of significance. The reason why the researchers use $90 \%$ confidence level is that most of category " $\mathrm{C}$ " taxpayers have homogenous character.

$\mathrm{n}=\mathrm{N} /\left(1+\mathrm{Nx}\left(\mathrm{e}^{2}\right)\right)$

Where;

- $\quad \mathbf{N}$ is the accessible population,

- $\mathrm{n}$ is the sample size and

- $\mathrm{e}$ is the error coefficient (since the population is too large, the researcher take e as $10 \%$ ) 
Based on the above formula the number of the sample) to be considered is calculated as follows:

$\mathrm{n}=\mathrm{N} /\left(1+\mathrm{Nx}\left(\mathrm{e}^{2}\right)\right)$

$\mathrm{n}=3860 /(1+3860(0.1) 2)$

$\mathrm{n}=97$

\subsection{Data type and source}

The primary source of data used to collect data for the study under taken. The primary source of data was generated from the business income tax payers through self-administered questionnaire which would be distributed to category ' $\mathrm{C}$ ' business income tax payers. With regard to the close- ended questions, the respondents were asked to indicate their level of agreement on a five point Likert scale with the following ratings. Strongly agree (SA; or $5)$, agree (A; or 4), neutral (N; or 3), disagree (D; or 2), and strongly disagree (SD; or 1$)$.

\subsection{Regression Model}

The dependent variable in this study is tax collection performance. tax collection performance is measured with the scales developed using the five-point Likert Scale of "1-Strongly Disagree", "2-Disagree", "3-Neutral", "4Agree" and "5-Stronly Agree". As per the hitherto existing literature, it is possible to measure these variables by primary data Questionnaire. This measure is expected to bring a reliable result after the collection of the data and its analysis.

The regression model below reveals that there is a relationship between one dependent variable (tax collection performance) against five independent variables (Tax law enforcement, Taxpayers attitude Educational level of taxpayers, Level of taxpayers actual income, and Tax system fairness) and therefore, Logit regression model used for the study. The general model to be estimated is the following forms:

\section{$\operatorname{Prob}($ event $)=\quad \frac{\operatorname{Exp}\{\mathrm{Bo}+\mathrm{B} 1 \mathrm{X} 1+--------\mathrm{BnXn}\}}{1+\operatorname{Exp}\{\mathrm{Bo}+\mathrm{B} 1 \mathrm{X} 1+----\mathrm{BnXn}}$}

Where $\mathrm{Xi}$ to $\mathrm{Xn}$ are explanatory variables that allowed to influence the probability of a positive response which is assumed to be the same for all items in the group, irrespective of the positive responses or the negative responses of the other items in that or any other group. Similarly, the probability of a negative response is defined as 1-p, for all items in the group (Anderson 1997). Therefore, the following model would be used in estimating the parameters for the variables in this study:

The full regression model for the empirical investigation in estimating factors that might explain the tax collection performance is given as:

$\mathrm{TCP} i=\beta 0+\beta 1 \mathrm{TLE} i+\beta 2 \mathrm{TPAi}+\beta 3 \mathrm{ELT} i++\beta 4 \mathrm{ACT} i+\beta 5 \mathrm{TSFi}+\mathrm{e}$

Where: $\quad \mathrm{TCP} i=$ tax collection performance

$\beta 0=$ value of TCPi if $\beta 1, \beta 2, \beta 3, \beta 4, \beta 5=0$

$\beta 1, \beta 2, \beta 3, \beta 4, \beta 5=$ coefficients of regression

TLE $i=$ Tax law enforcement $\quad$ TPA $i=$ Tax payers attitude $\quad$ ELTi $=$ Educational level of tax payers

$\mathrm{ACT} \mathrm{i}=$ Level of tax payers actual income TSF $\mathrm{i}=$ Tax system fairness $\quad \mathrm{e}=$ error term

\subsection{Method of Data analysis}

The research is designed to follow a mixed method. To this end, both qualitative and quantitative analyses were used. Data collected using questionnaire analyzed through descriptive statistics, frequency distribution, correlation and logit Regression using Statistical Package for the Social Scientists (SPSS).

\section{Results and Data Analysis}

This chapter explains and discusses the results of findings and analysis done on the data collected.

\subsection{Pearson Correlation Analysis}

The table below shows the results of the Pearson correlation analysis among the variables 
Table 4.1 Pearson correlation

\begin{tabular}{|c|c|c|c|c|c|c|}
\hline & TCP & TLE & TPA & ELT & ACT & TSF \\
\hline $\begin{array}{c}\text { TCP } \\
\text { Sig. (2-tailed) } \\
\mathrm{N}\end{array}$ & $\begin{array}{ll}1 & - \\
97 & \end{array}$ & & & & & \\
\hline $\begin{array}{c}\text { TLE Correlation } \\
\text { Sig. (2-tailed) } \\
\mathrm{N}\end{array}$ & $\begin{array}{l}.431 * * \\
.000 \\
97\end{array}$ & $\begin{array}{c}1 \\
- \\
97\end{array}$ & & & & \\
\hline $\begin{array}{c}\text { TPA Correlation } \\
\text { Sig. (2-tailed) } \\
\mathrm{N}\end{array}$ & $\begin{array}{l}.502 * * \\
.000 \\
97\end{array}$ & $\begin{array}{c}.497 * * \\
.000 \\
97\end{array}$ & $\begin{array}{c}1 \\
- \\
97\end{array}$ & & & \\
\hline $\begin{array}{c}\text { ELT Correlation } \\
\text { Sig. (2-tailed) } \\
\mathrm{N} \\
\end{array}$ & $\begin{array}{c}.689 * * \\
.000 \\
97 \\
\end{array}$ & $\begin{array}{c}.415^{* *} \\
.000 \\
97 \\
\end{array}$ & $\begin{array}{c}.511 * * \\
.000 \\
97\end{array}$ & $\begin{array}{l}1 \\
- \\
97 \\
\end{array}$ & & \\
\hline $\begin{array}{c}\text { ACT Correlation } \\
\text { Sig. (2-tailed) } \\
\mathrm{N}\end{array}$ & $\begin{array}{l}.323 * * \\
.000 \\
97\end{array}$ & $\begin{array}{c}.346 * * \\
.000 \\
97\end{array}$ & $\begin{array}{c}.283 * * \\
.000 \\
97\end{array}$ & $\begin{array}{c}.283 * * \\
.000 \\
97\end{array}$ & $\begin{array}{c}1 \\
- \\
97\end{array}$ & \\
\hline $\begin{array}{c}\text { TSF Correlation } \\
\text { Sig. (2-tailed) } \\
\mathrm{N}\end{array}$ & $\begin{array}{l}.392 * * \\
.000 \\
97 \\
\end{array}$ & $\begin{array}{r}.430 * * \\
.000 \\
97 \\
\end{array}$ & $\begin{array}{l}.321 * * \\
.000 \\
97^{.00} \\
\end{array}$ & $\begin{array}{r}.402 * * \\
.000 \\
97 \\
\end{array}$ & $\begin{array}{c}.218 * \\
.000 \\
97 \\
\end{array}$ & $\begin{array}{l}1 \\
- \\
97 \\
\end{array}$ \\
\hline
\end{tabular}

**. Correlation is significant at the 0.01 level (2-tailed).

*. Correlation is significant at the 0.05 level (2-tailed).

Source: SPSS correlation result

As shown in the above table, of the five explanatory variables tested in this study, there is a significant correlation between the variables (Tax law enforcement, Taxpayers attitude, Educational level of tax payers, Level of tax payers actual income, Tax system fairness) and tax collection performance. The correlation between these five variables and tax collection performance has a very strong value. Based on the results in table 4.1 there are positive relationships between tax collection performance and all of the independent variables, these shows that all of the hypotheses are supported.

\subsection{Logistic Regression Analysis}

Table 4.2 testing the model through ANOVA (Goodness of fit statistic)

\begin{tabular}{|l|l|l|l|l|l|}
\hline Model & Sum of Squares & df & Mean Square & F & Sig. \\
\hline Regression & 10.395 & 5 & 2.0895 & 16.7668 & $.000 \mathrm{a}$ \\
Residual & 11.8624 & 91 & 0.1666 & & \\
Total & 22.2574 & 96 & & & \\
\hline
\end{tabular}

a. Predictors:(Constant), TLE, TPA, ELT, ACT, TSF

b. Dependent Variable: TCP

Source: SPSS regression result

The above table summarizes the information about the variation of the dependent variable explained by the existing model used for this study and the residual that indicates the variation of the dependent variable that are not captured by the model. It is observed that the independent variables give a significant effect on the dependent variable, where F-value is 16.7668 with a p-value of less than 0.05 (i.e. $p<0.000$ ) indicating that, over all, the model used for the study is significantly good enough in explaining the variation on the dependent variable. To ensure the statistical adequacy of the model, the goodness of fit can also be measured by the square of the correlation coefficient also called R2.

Table 4.3 Goodness of fit through R Square

Model Summary

\begin{tabular}{|l|l|l|l|l|}
\hline Model & R & R Square & Adjusted R Square & $\begin{array}{l}\text { Std. Error of the } \\
\text { Estimate }\end{array}$ \\
\hline 1 & 1.0839 & 0.8583 & 0.65 & 0.548864 \\
\hline
\end{tabular}

a. Predictors: (Constant), TLE, TPA, ELT, ACT, TSF

Source: SPSS regression result

As shown in the table above, both R2 and adjusted R2 measure the fitness of the model i.e. they measure the proportion of the variation in dependent variable explained by the model. But since adjusted R2 is the modification for the limitation of R2 the value of the adjusted R2 is considered to measure the fitness of the model. Thus, as it is shown on table 4.3, the value of adjusted R2 is 0.65 , indicating that the independent variables in the model are 
explaining $65 \%$ variation on the dependent variables. Thus, we can understand that the model of the study is providing a good fit to the data. This outcome empirically indicates that the independent variables in this study are the major determinants of Tax collection performance.

Table 4.4. Below shows the results of the regression model. The result reveals that there exists a significant relationship between independent variables such as Tax law enforcement, Taxpayers attitude, Educational level of taxpayers, Level of tax payers actual income, Tax system fairness and dependent variable, i.e. tax collection performance

Table 4.4 Regression analysis on tax collection performance.

\begin{tabular}{|l|l|l|l|}
\hline Variables & Coefficients & t-statistic & Prob. \\
\hline Constant & 3.8814 & 14.4839 & .000 \\
\hline Tax law enforcement & 0.0043 & 0.5867 & 0.056 \\
\hline Taxpayers attitude & 0.3683 & 3.983 & 0.050 \\
\hline Educational level of taxpayers & 0.3975 & 3.9893 & 0.057 \\
\hline Level of tax payers actual income & 0.16623 & 4.4727 & 0.014 \\
\hline Tax system fairness & 0.1887 & 4.3383 & 0.010 \\
\hline
\end{tabular}

Source: SPSS regression result

As shown in the above table, of the total five explanatory variables tested in this study, Tax law enforcement $(p$-value $=0.056)$, Taxpayers attitude $(p$-value $=0.050)$, Educational level of taxpayers, $(p-v a l u e=0.057)$, Level of taxpayers actual income $(p$-value $=0.014)$, and Tax system fairness ( $p$-value $=0.010)$ were statistically significant at 10 percent or lower. In this study, the result reveals that there is a significant positive relationship between all the independent variables and tax collection performance

Analysis

In the next section the effect of each independent variable tested under this study is discussed and analyzed based on the theoretical predictions, prior empirical studies and hypothesis formulated for this study.

Tax law enforcement: In this study both the Pearson correlation and regression results indicate that there is significant relationship between Tax law enforcement and tax collection performance. The results of the Pearson correlation indicate that the value for the correlation coefficient $(r)$ is 0.431 and significant at 0.1 . On the other hand the results of the regression analysis shows there is strong relationship between Tax law enforcement and tax collection performance, with a regression coefficient of 0.0043 , t-statistic of 0.5867 and P-value of 0.056 . This indicates that this value is significant to further the relationship with tax collection performance. Therefore, the first hypothesis is accepted. This implies the strong the law enforcement, the minimum the likelihood of efficient tax collection. Therefore, the authority demanded stringent law improvement.

Taxpayers attitude: In this study, both the correlation and the regression result shows there is a significant positive relationship between Taxpayers attitude and tax collection performance. As it is presented on table 4.1, the Pearson correlation result shows a significant correlation between Taxpayers attitude and tax collection performance with correlation coefficient of $r=0.502$ and significant at 0.05 . The regression result also shows a significant relationship between Taxpayers attitude and tax collection performance, with a regression coefficient of 0.3683 , t-statistic of 3.983 and P-value of 0.050 . Thus, from the result it can be concluding when taxpayers have a positive attitude towards paying taxes, tax compliance will increase. This result is consistent with the hypothesis of the study. However, from the descriptive statistics the researcher infer that tax administration have negative attitude by taxpayers that the negative attitude hinders tax administration of the city.

Educational level of taxpayers: As presented on table 4.1, there is a positive correlation between Educational level of taxpayers and tax collection performance with a correlation coefficient of 0.689 and significant at 0.1 . The correlation between Educational level of taxpayers and tax collection performance has a very good value. Similarly the regression result shows a significant positive relationship between Educational level of taxpayers and tax collection performance, with a regression coefficient of 0.3975 , t-statistic of 3.9893 and P-value of 0.057 . This indicates that knowledgeable taxpayers are will not develop non-compliance behavior which increase tax collection performance.

Actual level of income: As presented on table 4.1, there is a positive correlation between level of income and tax collection performance with a correlation coefficient of 0.323 and significant at 0.05 . The correlation between level of income and tax collection performance has a very good value. Similarly the regression result shows a significant positive relationship between level of income and tax collection performance, with a regression coefficient of 0.16623 , t-statistic of 4.4727and P-value of 0.014.This indicates that if the level of actual income declines, then this may discourage tax compliance and decline in tax collection performance and the result is consistent with the hypothesis of the study.

Tax system fairness: In this study, both the correlation and the regression result shows there is a significant positive relationship between Tax system fairness and tax collection performance. As it is presented on table 4.1, the Pearson correlation result shows a significant correlation between Tax system fairness and tax collection performance with correlation coefficient of 0.392 and significant at 0.1 . The regression result also shows a 
significant relationship between tax system fairness tax collection performance, with a regression coefficient of 0.1887 , t-statistic of 4.3383 and P-value of 0.010 . This suggests that if the attitude of taxpayers is positive and if they perceive the tax system fairly, then tax compliance increase. This implies that if tax assessment is perceived to be fair by taxpayers, it would have a positive impact on tax collection performance .This result is consistent with the hypothesis of the study.

\section{Conclusions:}

The survey results revealed that overall, tax collection performance is positively affected by tax authority light law enforcement ,positive attitude of taxpayers towards tax , the amount of tax knowledge by the taxpayers, the actual level of taxpayers income, and the fair tax system especially in tax estimation. When the logit regression model of tax collection performance was applied, the $R 2$ value was $65 \%$.The $R 2$ values are classified by Cohen (1988) as a good result (i.e. above 0.26) for the behavioral sciences. Collectively, the five determinants in the model were considered to be good predictors of tax collection and compliance performance. The descriptive survey result also revealed that tax authority faces challenges in tax collection like many tax payers found themselves rejecting the daily income estimation, taxpayers are not even willing to pay tax, they lack awareness on why they pay tax. The descriptive statistics also revealed that the taxpayers are facing challenges like the income estimation by the tax authority does not consider the taxpayers actual income, and daily turnover, the taxpayers will not get appropriate answer from tax authority for re- estimation, unskilled and inefficient estimators and fairness related problem.

\section{Recommendations:}

The tax authority should be clear of the way of tax estimation, what and how presumptive taxation applicable to tax payers through discussion agendas with taxpayers.

The tax authority should have skilled manpower that can able to understand the tax legislation and able to train taxpayers, and curious to develop new tax issues.

The tax authority should create awareness towards the taxpayers why tax are levied from them and change the negative attitude of taxpayers towards tax.

\section{References}

Abate Gashaw (2019), Investigation of Value Added Tax Administration Challenges In Debre Markos Town, International Journal of Research in Economics \& Social Sciences Vol. 9 Issue 12 Page 49-50

Abebaw belete (2019), Challenges Of Tax Assessment And Its Consequences On Tax Collection On Category " $C$ " Taxpayers: The Case Of Debre Markos City Administration, Debre Markos university, Ethiopia

Allingham, M. \& Sandmo, A. (1972), 'Income tax evasion: a theoretical analysis', Journal of Public Economics, $1,323-338$

Creswell, J W 2013, Research design: qualitative, quantitative and mixed methods approaches, 4th ed., Sage Publications, California

Eshag, E. (1983), Fiscal and monetary problems in developing countries. London: Cambridge University Press.

Federal democratic republic of Ethiopia: Income Tax Proclamation No.979/2016

Kasippilai, J. (2000),Taxpayer knowledge index as a clue for non-compliance. Journal on Pakistan's Taxation Laws, 81(3).

Kirchelr E. (2007), the economic psychology of tax behavior: Cambridge university press.

Kirchler E., S Muehlbacher, B. Kaslunger B. (2007), why pay taxes? A review of tax compliance decisions. Working paper:Georgia state university Atlanta.

Misrake Tesfay (2008), Ethiopian tax accounting theory and practice, Addis Ababa, Ethiopia

Spicer, M.W. and Lundstedt, S.B. (1976) Understanding Tax Evasion. Public Finance/Finances Publiques, 31 , 295-305.vol. 31, issue 2, 295-305

WBG. (2007), Designing a tax system for micro and small businesses: Guide for Practitioners.

Wilson, J. (2010), Essentials of business research: a guide to doing your research project, SAGE Publication.

Wilson Prichard (2010), Taxation and State Building: Towards a Governance Focused Tax Reform Agenda, IDS working paper issue $341,01-55$ 